\title{
Publisher Correction: A
}

\section{global database of Holocene paleotemperature records}

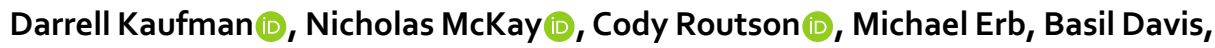

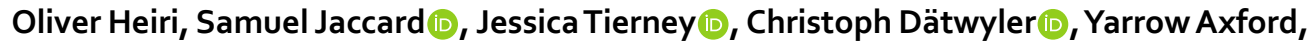
Thomas Brussel, Olivier Cartapanis, Brian Chase, Andria Dawson, Anne de Vernal,

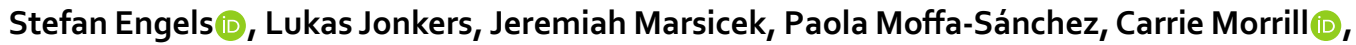
Anais Orsi, Kira Rehfeld, Krystyna Saunders, Philipp S. Sommer $\mathbb{D}$, Elizabeth Thomas $\mathbb{D}_{\text {, }}$ Marcela Tonello, Mónika Tóth, Richard Vachula, Andrei Andreev, Sebastien Bertrand (D, Boris Biskaborn, Manuel Bringué (D), Stephen Brooks, Magaly Caniupán, Manuel Chevalier,

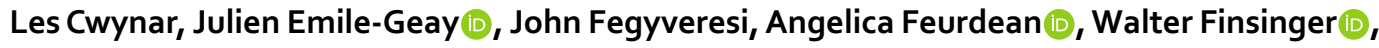
Marie-Claude Fortin, Louise Foster, Mathew Fox, Konrad Gajewski (D, Martin Grosjean (D, Sonja Hausmann, Markus Heinrichs, Naomi Holmes, Boris Ilyashuk, Elena llyashuk, Steve Juggins $\mathbb{D}$, Deborah Khider, Karin Koinig $(\mathbb{D}$, Peter Langdon, Isabelle Larocque-Tobler, Jianyong Li, André Lotter, Tomi Luoto D, Anson Mackay, Eniko Magyari, Steven Malevich, Bryan Mark, Julieta Massaferro, Vincent Montade, Larisa Nazarova, Elena Novenko, Petr Pařil D, Emma Pearson, Matthew Peros, Reinhard Pienitz, Mateusz Płóciennik, David Porinchu, Aaron Potito, Andrew Rees, Scott Reinemann, Stephen Roberts, Nicolas Rolland (iD, Sakari Salonen ${ }^{D}$, Angela Self, Heikki Seppä (i), Shyhrete Shala, Jeannine-

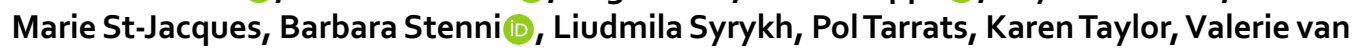

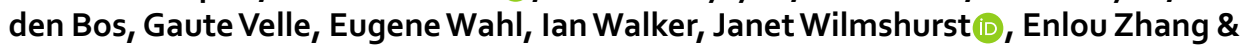
Snezhana Zhilich (i)

Correction to: Scientific Data https://doi.org/10.1038/s41597-020-0445-3, published online 14 April 2020

In an earlier version of this Data Descriptor the figure images 4, 5 and 6 were swapped.

Both the HTML and PDF versions have been updated to reflect this change.

(c) (i) Open Access This article is licensed under a Creative Commons Attribution 4.0 International License, which permits use, sharing, adaptation, distribution and reproduction in any medium or format, as long as you give appropriate credit to the original author(s) and the source, provide a link to the Creative Commons license, and indicate if changes were made. The images or other third party material in this article are included in the article's Creative Commons license, unless indicated otherwise in a credit line to the material. If material is not included in the article's Creative Commons license and your intended use is not permitted by statutory regulation or exceeds the permitted use, you will need to obtain permission directly from the copyright holder. To view a copy of this license, visit http://creativecommons.org/licenses/by/4.0/.

(C) The Author(s) 2020 